\title{
AUTUMN NITROGEN FERTILISER IN A DRYLAND SHEEP SYSTEM
}

\author{
J.H. Hoglund and C.G.L. Pennell
} Grasslands Division, DSIR, Lincoln

\begin{abstract}
Applying $50 \mathrm{~kg} \mathrm{~N} / \mathrm{ha}$ to dryland ryegrass-white clover pasture in autumn in each of four years resulted in an increased carrying capacity over the control for the last two years of $137 \mathrm{~kg}$ liveweight per ha at minimum in December, with an early spring peak of $211 \mathrm{~kg}$ extra liveweight per ha. Despite higher stocking rates on $\mathrm{N}$-treated pastures in the later years. feed on offer at grazing was greater from early winter until the onset of severe drought, typically 8 months later. grazing was greater from early winter until the onset of severe drought, typically 8 months later.
This improved level of feeding lifted ewe bodyweights post lambing by at least $4 \mathrm{~kg}$. These higher ewe body weights were associated with significantly higher birth weights of twin lambs. Daily growth rates of these lambs. in a flock averagıng better than $175 \%$ lambing, were in excess of $260 \mathrm{~g} / \mathrm{head}$ when ewe bodyweights were over60 $\mathrm{kg}$ post lambing.
\end{abstract}

Keywords: Nitrogen fertiliser, sheep grazing, lamb growth rates

\section{INTRODUCTION}

Lamb production on summer-dry farms in cool climates must take maximum advantage of the relatively short spring growing season, with the objective of quitting the lambs before the onset of summer drought. Early drafting allows time for ewes to regain condition before tupping and the start of the next production cycle. The need to quit lambs relatively early can conflict with the desire to produce heavy lambs. Extending the lamb growing season by earlier lambing is constrained by availability of quality greenfeed during late pregnancy and early lactation.

Winter soil temperatures are too low to allow use of nitrogen (N) fertiliser immediately before lambing to boost feed supplies, while autumn applications have generally been considered unreliable. However, most $\mathbf{N}$ fertiliser trials have reported only short-term results and the one reported in this paper investigated longer term effects in a dryland sheep grazing system with autumn $\mathbf{N}$ applications repeated in each of four years.

\section{METHODS}

The trial was autumn sown in 1982 at a site close to Lincoln on a Templeton soil with Eyre intrusions. Two clover seedlines, 'Grasslands Huia' and an experimental inbred line, both sown with 'Grasslands Nui' perennial ryegrass, provided pastures with contrasting clover contents. Calcium ammonium nitrate at $50 \mathrm{~kg} \mathrm{~N}$ was applied to half of the area during the first fortnight in April, as two equal split dressings. The first $\mathrm{N}$ application was 12 months after sowing in autumn of 1983.

The area was fenced into 32 separate paddocks, comprising 9 paddocks of each of these four $\mathrm{N} /$ clover treatments (totalling 0.91 ha/treatment). Treatments were randomly allocated within each of the 8 replicate blocks. Each treatment was separately stocked with a high fecundity flock of Coopworth ewes, each of the 8 paddocks being grazed in sequence. Winter rotation was approximately 90 days, summer about 60 days, with a 16 -day rotation for the remainder of the year.

Lambing began in mid August with lambs run with their mothers until drafting in early December. Each treatment was substantially self-contained with the additional objective of avoiding the making and/or use of conserved supplementary 
feeds. However, very low feed availability on minus $\mathbf{N}$ treatments in early August 1985 necessitated removal of stock on to greenfeed for 10 days to counter sleepy sickness. Stocking rates on each treatment were intially adjusted no more than twice a year with a view to achieving similar mean ewe bodyweights, within an annual range of 50-60 $\mathrm{kg}$, on each treatment. Dry ewes were culled during early spring and replacements added before flushing. In the even of uneven loss of ewes, through failure to get in lamb or through misadventure at lambing, mobs were adjusted to maintain stocking rate differentials.

Results reported here cover predominantly the last two years, the fourth and fifth from sowing, during which time the stocking rate differential between plus- and minus- $\mathbf{N}$ treatments was stable. In any one year each mob contained 13 to 16 ewes, depending on treatment. Lamb performance data are based on a total of 385 lambs dropped over 4 years. Regressions between variables were calculated on a mob basis, using data from all treatments and years $(n=16)$, but tabular data are given only for the last 2 years of the Huia treatments.

\section{RESULTS AND DISCUSSION}

The target bodyweights resulted in stocking rate differentials of 2.2 ewes per ha (15.0 v. 17.2 at mating for Huia treatments) between $\mathrm{N}$-treated pastures and the controls during the last 2 years. There was a marked contrast in the seasonal variation of bodyweights. The ewe bodyweight advantage on $\mathbf{N}$ treatments was maximum post lambing, with a minimum around drafting time. This was reflected in the seasonal variation in total liveweight carried on each treatment (Table 1). In contrast, ewes'in the $\mathbf{N}$ treatment lost weight during lactation relative to the control ewes, presumably reflecting reduced feed availability as a result of the stocking rate differential. Flushing through tupping was another period of relative stress for the $\mathrm{N}$ treatment ewes, again presumably a result of the stocking rate differential, with $23 \%$ less liveweight gain (LWG) during this period ( 3 weeks before puttig ram out through to end of first cycle).

Over all treatments and seasons, lambing percentage (lambs dropped per ewe mated) was positively ( $P<0.01)$ related to the flushing liveweight gain (LWG), with a slightly high proportion of dry ewes on the $\mathrm{N}$ treatment $(5.3 \% \mathrm{v} 2.5 \%)$;

$$
\text { Lambing } \%=1.48+0.099 . \mathrm{LWG}
$$

$$
\text { (SD) }(0.09)(0.029)^{\star \star}
$$

There was no improvement in fit through including mean static liveweight effects.

The reduction in lambing percentage resulting from poorer flushing on $\mathbf{N}$ treatments offset the higher stocking rates, so that similar numbers of lambs were dropped on both treatments. Lamb survival, albeit variable, was slightly better on the $\mathrm{N}$ treatments. This agrees with previously published results (Holst et al. 1986; Kelly 1987) which demonstrated positive correlations between lamb birth weights up to about $4.5 \mathrm{~kg}$ and lamb survival. In the present trial lambs from $\mathrm{N}$ treatments were on average $0.24 \mathrm{~kg}$ heavier for twins (Table 2) and $0.49 \mathrm{~kg}$ overall $(4.17 \vee 4.66 \mathrm{~kg}$ ).

Heavier lambs posed no problems and no assistance was required at lambing in this high fertility easy care flock, with the exception of mis-mothering problems resulting from our rotational grazing management. Holst et al (1986) and Kelly (1987) also demonstrated positive correlations between lamb birth weights and ewe weights in the 40-50 kg liveweight range. Those ewes were lighter than the ewes reported here, but the results are, nonetheless, consistent.

The strongest advantage of higher ewe liveweights at lambing, however, was the positive association $(\mathrm{P}<0.001)$ with subsequent lamb growth rate, presumably a result of greater ewe milk yields. In the year in which ewe liveweights exceeded 60 kg post lambing, subsequent daily lamb growth rates were in excess of $280 \mathrm{~g} / \mathrm{head}$ 
Table 1: Carrying capacity of control and $\mathrm{N}$-fertilised dryland pastures at selected times of the year (kg liveweight per ha)

\begin{tabular}{|c|c|c|c|}
\hline & control & $+N$ & difference \\
\hline pre flushing & a43 & 986 & 143 \\
\hline post fupping & 890 & 1027 & 137 \\
\hline post lambing - ewes & 783 & 970 & 187 \\
\hline lambs & 85 & 109 & 24 \\
\hline -total & 868 & 1079 & 211 \\
\hline pre drafting - ewes & 818 & 902 & 84 \\
\hline - lambs & 576 & 655 & 79 \\
\hline- total & 1394 & 1557 & 163 \\
\hline
\end{tabular}

Table 2: Mean per head performance data for ewes and lambs grazing $\mathrm{N}$-fertilised and control Huia dryland pastures during the two years $1985-86$ (stocking rate differential was $2.2 \mathrm{ewes} / \mathrm{ha}$ )

\begin{tabular}{lccc}
\hline & control & $+\mathrm{N}$ & $\begin{array}{c}\text { significance } \\
\text { of difference }\end{array}$ \\
\hline Ewes post lambing $(\mathrm{kg} \mathrm{LW})$ & 49.7 & 54.9 &.. \\
Twin birth weights $(\mathrm{kg})$ & 4.08 & 4.32 &. \\
Lamb growth rates $(\mathrm{g} / \mathrm{head})$ & 210 & 204 & $\mathrm{~ns}$ \\
Lambs at drafting $(\mathrm{kg})$ & 28.1 & 28.1 & $\mathrm{n} \mathrm{s}$ \\
\hline
\end{tabular}

Table 3: Year-to-year variation in stocking rate and total system pre-lambing feed availability for control and autumn $\mathrm{N}$-tertilised pastures

\begin{tabular}{rcccc}
\hline \multicolumn{2}{l}{ Date } & \multicolumn{2}{c}{ Stocking rate (ewes/ha) } & \multicolumn{2}{c}{ Mean system yield (kg DM/ha) } \\
& control & $+\mathbf{N}$ & control & $+\mathbf{N}$ \\
\hline $13 / 7 / 83$ & 15 & 15 & 594 & 948 \\
$6 / 7 / 84$ & 14 & 15 & 969 & 1442 \\
$17 / 7 / 85$ & 14 & 16 & 298 & 402 \\
$15 / 7 / 86$ & 13 & 15 & 527 & 682 \\
\hline
\end{tabular}

despite three quarters of the lambs being reared as twins.

Including ewe LWG from lambing to weaning in the model as a measure of relative per head spring feed availability, improved regression fit viz:

Lamb GR = -115 + 6.32.eweLW at lambing + 2.93.eWeLWG to weaning

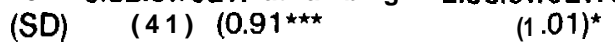

Thus heavier ewes at lambing in $\mathbf{N}$ treatments generally offset depressive spring stocking rate effects, with a net result of similar lamb growth rates in both control and $\mathrm{N}$ treatments (Table 2), despite 2.2 extra ewes and 2.8 extra lambs per ha

Autumn $\mathrm{N}$ fertiliser slightly boosted autumn growth, increased feed on offer before each grazing and residuals post grazing, and increased rate of pasture recovery from winter grazings, all culminating in greater greenfeed availability before lambing (Table 3). In the last 2 years of the trial, $50 \mathrm{~kg} \mathrm{~N}$ applied in the autumn triggered a chain of events leading to increased animal production consisting of the wool from 2.2 extra ewes plus 2.8 extra lambs per ha. Even at current prices (2.8 lambs @ \$17.50 each; 9 kg wool @ \$4.50/kg), this represents a gross return of approximately $\$ 90 / \mathrm{ha}$. The future potential of autumn $\mathbf{N}$ fertiliser may, however, lie in the ability to confidently adopt a slightly earlier lambing date and thus extend the lamb growth season. Initial pre-lambing concern about high bodyweight ewes proved to be unfounded in this flock selected for high fertility and easy lambing. Indeed on reflection, and with an appreciation of the significance of ewe bodyweight to twin lamb birth weights and their subsequent performance, the result may have been even better through taking a higher bodyweight, lower stocking rate path. Slightly lower stocking rates than those used in this trial, in 
conjunction with an early August lambing, should consistently enable daily lamb growth rates of $265 \mathrm{~g} / \mathrm{head} /$ day on autumn $\mathrm{N}$-fertilised pasture, thus producing twin lambs of $40 \mathrm{~kg}$ liveweight at drafting before Christmas.

\section{References}

Holst, P.J.; Killeen, I.D.; Cullis, B.R. 1966. Nutrition of the pregnant ewe and its effect on gestation, length, lamb birth weight and lamb survival. Australian journal of agricultural research 37: 647-55.

Kelly, R. 1967. Survival of lambs. Western Australia journal of agriculture 28: 99-103. 